https://helda.helsinki.fi

\title{
The Helios-and-Zodiac Motif in Late Antique Synagogues
}

\section{Bonnie, Rick}

Vandenhoeck \& Ruprecht

2021

Bonnie , R 2021 , The Helios-and-Zodiac Motif in Late Antique Synagogues . in K Valkama \& N Nikki (eds), Magic in the Ancient Eastern Mediterranean : Cognitive, Historical, and Material Perspectives on the Bible and Its Contexts. Mundus Orientis , no. 3 , Vandenhoeck \& Ruprecht , Göttingen , pp. 299-311 . https://doi.org/10.13109/9783666522185.299

http://hdl.handle.net/10138/337792

https://doi.org/10.13109/9783666522185.299

cc_by

acceptedVersion

Downloaded from Helda, University of Helsinki institutional repository.

This is an electronic reprint of the original article.

This reprint may differ from the original in pagination and typographic detail.

Please cite the original version. 
Published as Bonnie, Rick. 2020. "The Helios-and-Zodiac Motif in Late Antique Synagogues." In Magic in the Ancient Eastern Mediterranean: Cognitive, Historical, and Material Perspectives on the Bible and Its Contexts, edited by Kirsi M. J. Valkama and Nina Nikki, 299-311. Mundus Orientis 3. Göttingen: Vandenhoeck \& Ruprecht. http://www.doi.org/10.13109/9783666522185.299.

\title{
The Helios-and-Zodiac Motif in Late Antique Synagogues
}

\author{
Rick Bonnie
}

During the Byzantine period (324-636 CE), the figure of Helios, the personification of the sun, surrounded by the zodiac signs and the personifications of the four seasons (henceforth, "Helios-andzodiac motif') became a common theme in synagogues in the region of present-day Israel and the Palestinian Territories. Excavations to date include seven mosaic floors covering the synagogues' central nave (Beth Alpha, Hammath Tiberias, Huqoq, Huseifa, Na'aran, Sepphoris, and Susiya) that attest this motif. To be sure, figurative art was already well attested in Jewish contexts (e.g., Beth She 'arim, Sepphoris, Dura Europos) before its appearance in the synagogues of Byzantine Palestine. Aside from Helios-and-zodiac motifs, some Byzantine synagogue floors were decorated with geometric designs and animal motifs. Others depicted biblical figures, such as the that of David with Goliath"s weaponry (Meroth) or that of Samson (Khirbet Wadi Hamam).

Nevertheless, of all the different floor designs in synagogues, the Helios-and-zodiac is by far the most consistent and most widespread. It is arguably also one of the oddest motifs, at least for modern interpreters. What do such seemingly "non-Jewish" elements as the astrological signs of the zodiac and the figure of Helios have to do with a place of Jewish worship, in a region with a significant Jewish population? Who commissioned these mosaics and for what reasons? How did ordinary congregants at these synagogues understand these motifs? As I discuss below, the answers to these questions have eluded scholars and, even after almost a century, has resulted in relatively little consensus. All things considered, the Helios-and-zodiac motif is arguably the most intriguing aspect of Jewish art in antiquity.

The reason this motif is so heavily debated is because its significance is central to the larger scholarly discussion on the development of rabbinic hegemony in Late Antique Palestine and the spread of a 
"mainstream" rabbinic Judaism during this period. ${ }^{1}$ Some have even interpreted the Helios-and-zodiac motifs as evidence for a spirited Hellenized mystical movement within Judaism in Late Antique Palestine. This movement or tradition developed in opposition to a "mainstream" Judaism that conformed and obeyed the laws disseminated by the rabbis (and preserved in their writings). This connection of the Helios-and-zodiac motif with Jewish mysticism has also linked it to discussions on Jewish magic. At least in its earlier views, Jewish magic was understood as a superstition that descended from non-Jewish environments and stood in opposition to the rationalist image of (rabbinic) Judaism cultivated in the nineteenth and early twentieth century. ${ }^{2}$ This understanding was deeply influenced by the view that Jewish mysticism and associated magical traditions constituted a culture of the common people, the am ha-aretz. Others, in rebuttal of the above claim that these motifs are to be understood as evidence for nonrabbinic Jewish movements, have tried to frame the appearance of the Helios-and-zodiac motifs in the context of rabbinic Judaism. According to this view, the rabbis, though they disapproved of the "non-Jewish" elements and symbols that were popular among the Jewish masses, were nevertheless quite tolerant toward them. Thus, these motifs indicate the cultural inclusiveness of the rabbinic movement at this time.

Ultimately, any individual's understanding of this motif is inevitably and inextricably entangled in his or her definition of what constituted Jewish identity in antiquity. This chapter aims to critically discuss the various interpretations that have been given for the appearance of the Helios-and-zodiac motif in several synagogues in Byzantine Palestine and to place these interpretations in the larger discussion on the nature and development of Judaism at this time. First, however, I will address the archaeological and cultural context of this motif.

\section{The Helios-and-Zodiac Motif: Description and Contextualization}

The earliest-attested Helios-and-zodiac motif is that decorating the synagogue of Hammath Tiberias (second half $4^{\text {th }}$ c. CE), a suburb of Tiberias on the west shore of the Sea of Galilee. ${ }^{3}$ Other well-

\footnotetext{
${ }^{1}$ See Schwartz 2002 for the history of this debate. In fact, the discussion on the nature and development of Judaism in Byzantine Palestine was to a large extent ignited by the first discoveries of Helios-and-zodiac motifs in synagogues (esp. the Beth Alpha mosaic, excavated in 1929).

${ }^{2}$ See Veltri 2010, 587-599, for the history of this debate. Current studies on Jewish magic often give only a few references to the scholarly discussion of the mosaic motif in synagogues. See, e.g., Wandrey 2004, 82-87; Bohak 2009: 251-253.

${ }^{3}$ Dothan 1983, 27-70. Although Dothan (1983, 66-67) dated the synagogue's construction phase - during which the mosaic was laid - to the early fourth century CE, most scholars nowadays agree that this date should be pushed to at least the second half of the fourth century CE. See, e.g., Dunbabin 1999, 189n6; Magness 2005, 10-13.
} 
preserved examples have been discovered in synagogues at Sepphoris (early $5^{\text {th }}$ c. CE) and at Beth Alpha $\left(6^{\text {th }} \mathrm{c} . \mathrm{CE}\right)$, located to the west of Beth She' an. ${ }^{4}$ One very recent finding of a Helios-and-zodiac mosaic program came in 2017 from the ongoing excavations in the synagogue at Huqoq (late $4^{\text {th }}$ to $5^{\text {th }}$ c. CE), a site located in the hills of Eastern Lower Galilee. ${ }^{5}$ The other three known Helios-andzodiac motifs are unfortunately very poorly preserved. The one in the synagogue of Susiya (late $4^{\text {th }}$ early $5^{\text {th }}$ c. CE), in the southern Judean mountains, was later covered over with a geometric mosaic, ${ }^{6}$ the one at Huseifa (mid- $5^{\text {th }}$ c. CE), on the slopes of Mt Carmel, has only one of the four seasons and a few zodiac signs surviving, ${ }^{7}$ and the one at $\mathrm{Na}$ 'aran $\left(6^{\text {th }} \mathrm{c}\right.$. CE), near Jericho, had its figures damaged by iconoclastic destruction. ${ }^{8}$ Aside from these cases, Helios-and-zodiac motifs may have also decorated the synagogues at Japhia, Khirbet Wadi Hamam and Beth She'an, but, unfortunately, too little has been preserved there to provide certainty. ${ }^{9}$

The Helios-and-zodiac motif comprises a square frame containing two concentric circles. In the central circle, the figure of the sun god Helios (or, at Sepphoris, a sun with ten rays) is depicted riding a chariot drawn by four horses (Figure 1). The outer, larger circle is divided into twelve radial units, each containing one of the astrological signs and its corresponding Hebrew name. The outer circle almost touches the four edges of the square frame, thereby creating four triangles in the corners in which the four seasons are depicted, personified as female busts, together with a Hebrew inscription of the month during which the corresponding season begins.

There are, however, also notable differences between the zodiac panels. For instance, the zodiac circles of the mosaics at $\mathrm{Na}$ aran and Huseifa run clockwise, while those of Hammath Tiberias, Sepphoris and Beth Alpha are depicted anticlockwise. In addition, while the astrological signs of the mosaics at Hammath Tiberias and Sepphoris neatly correspond to the seasons depicted in the panels' corners, those at Huseifa, Beth Alpha and $\mathrm{Na}$ 'aran betray no discernible coordination of the sort.

\footnotetext{
${ }^{4}$ Sepphoris: Weiss 2005, 104-141; Beth Alpha: Sukenik 1932.

5 "Excavations by UNC-Chapel Hill Archaeologist Continue to Yield Stunning Mosaics in Ancient Galilean Synagogue," The University of North Carolina at Chapel Hill News, July 6, 2017, http://uncnews.unc.edu/2017/07/06/excavations-uncchapel-hill-archaeologist-continue-yield-stunning-mosaics-ancient-galilean-synagogue/. Since the Helios-and-zodiac mosaic panel from the Huqoq synagogue has not been published yet, it is not further included in this discussion. For an extensive preliminary report on the Huqoq synagogue, see Magness et al. 2014; 2018.

${ }^{6}$ Gutman, Yeivin and Netzer 1981, 126.

${ }^{7}$ Avi-Yonah 1934.

${ }^{8}$ Vincent 1919, 1921, 1961.

9 Japhia: Barag 1993; Khirbet Wadi Hamam: Leibner and Miller 2010, 239-240; Beth She'an: Zori 1967; Hachlili 2013, Fig. V-33.
} 
Finally, the zodiac figures of the mosaics at Hammath Tiberias, Sepphoris and Huseifa have their heads directed toward the central circle, while, of those at Beth Alpha and $\mathrm{Na}$ 'aran, the figures radiate outward, with their feet pointed to the central circle.
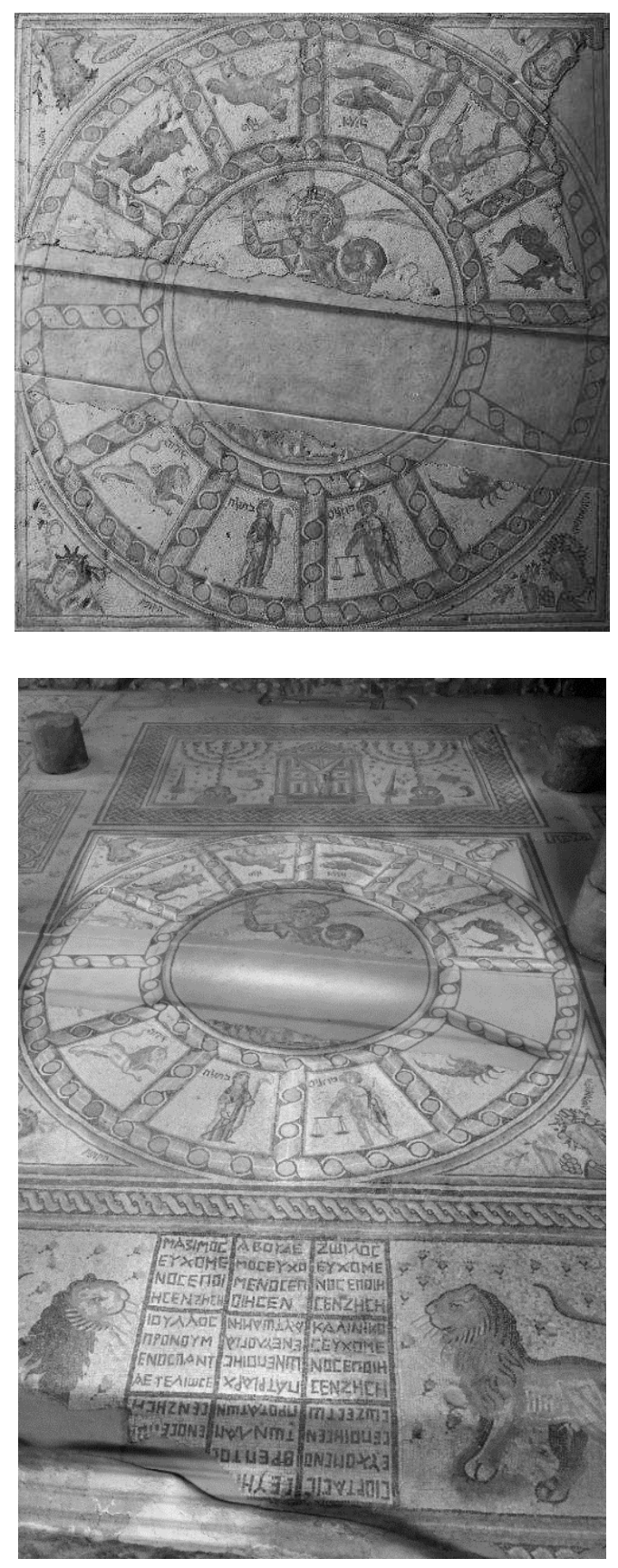

Figure 1. Helios-and-zodiac motif in the synagogue of Hammath Tiberias (photo: Juha Pakkala).

Figure 2. Helios-and-zodiac motif within its broader mosaic setting in the synagogue of Hammath Tiberias (photo: author). 
It should be further noted that the Helios-and-zodiac motif is not an isolated mosaic depiction. Instead, in all seven attested cases, the Helios-and-zodiac motif is the centre of a much larger mosaic composition decorating the synagogues' central naves (Figure 2). At Hammath Tiberias, for example, a rectangular panel with eight Greek dedicatory inscriptions flanked by two heraldic lions borders the Helios-and-zodiac motif on the side nearest to the synagogue's entrance, while, on the other side, near the synagogue's Torah shrine, a rectangular panel displays a Torah shrine flanked by pairs of Jewish symbols (menorot, shofarot, lulavim, ethrogim and incense shovels). A roughly similar tripartite scheme is attested in the mosaic at Beth Alpha. The most notable difference is the fact that the panel near the entrance here depicts the biblical scene of the Binding of Isaac, including Hebrew inscriptions in reference to Gen 22:12 as well as identifying Abraham and Isaac.

The composition of the other mosaic floors shows more variation (e.g., Sepphoris's mosaic consists of seven panels instead of three), but the scenes depicted notwithstanding bear considerable likeness to those at Hammath Tiberias and Beth Alpha. The Binding of Isaac is also depicted at Sepphoris, for instance, and other biblical scenes are attested, such as the angels' visit to Abraham and Sarah (Sepphoris) and Daniel in the Lions' Den (Na'aran, Susiya). Furthermore, the panel of a Torah shrine flanked by Jewish symbols is always depicted and, with one exception (Huseifa, where the panel is located near the synagogue's entrance), located near the synagogue's actual Torah shrine. The one mosaic floor composition in which the depictions surrounding the Helios-and-zodiac motif, from what has been uncovered and published so far, resembles the others least is the mosaic floor of the Huqoq synagogue. However, the excavations at Huqoq are still ongoing, its mosaic floor has yet to be fully laid bare and a full description and interpretation of this mosaic composition by the excavators has yet to be made. ${ }^{10}$

Thus, the mosaic floors found in the seven synagogues in general and the Helios-and-zodiac motifs in particular bear significant resemblance with one another, while, at the same time, betraying notable differences. The context of where and when these Helios-and-zodiac motifs appeared in synagogues likewise hinges on questions of "likeness" and "diversity." On the one hand, there is no discernible pattern in the spatial and chronological distribution of these mosaic floors; they are found in diverse localities across Palestine (both rural and urban) from various times during the Byzantine period

\footnotetext{
${ }^{10}$ For a description of the mosaic panels uncovered thus far, see Magness et al. 2014 and the annual preliminary reports published in Hadashot Arkheologiyot - Excavations and Surveys in Israel (www.hadashot-esi.org.il).
} 


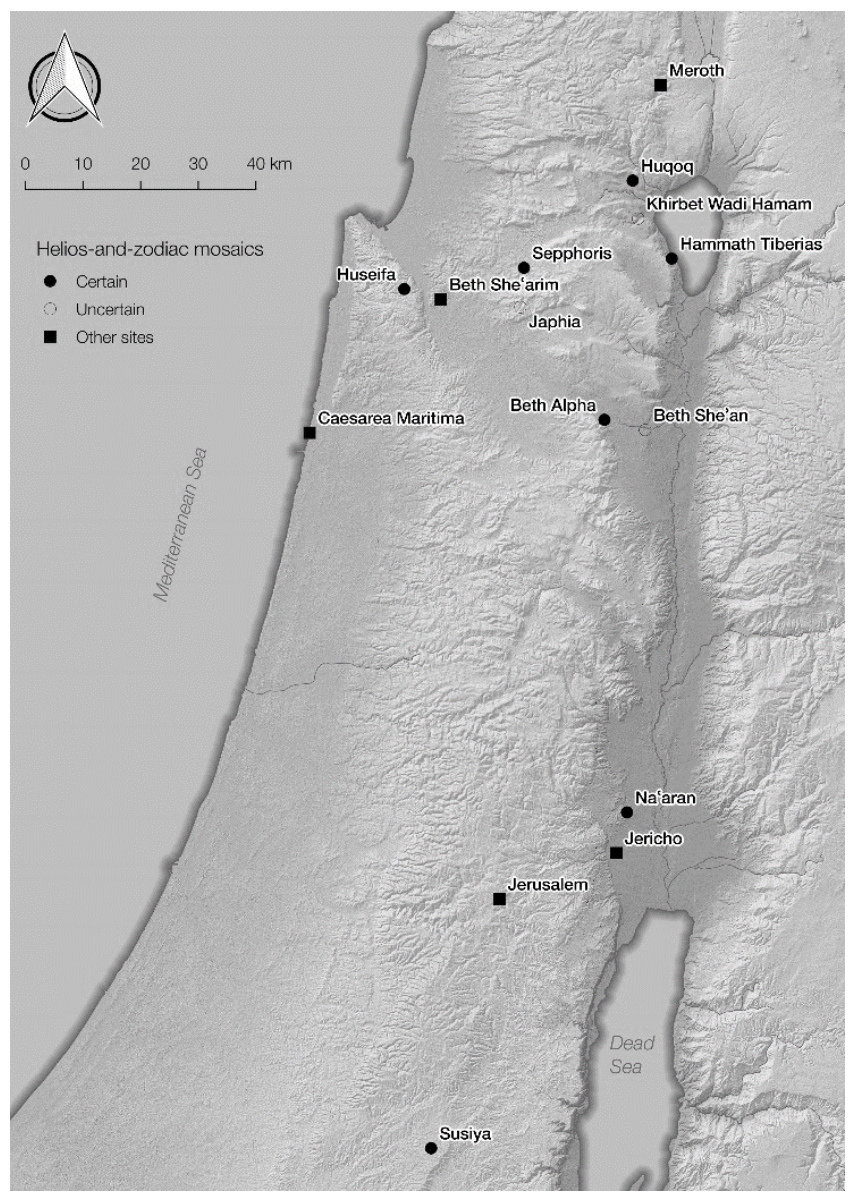

Figure 3. Map of Roman Palestine with the location of places mentioned in the text (drawn by author).

(Figure 3). On the other hand, although the motif was a Jewish adoption from the wider Græco-Roman world, the iconographic program seems to have been quite purposefully tailored to Jewish worship contexts. Indeed, the closest contemporary iconographic parallels to the Helios-and-zodiac motif in Palestinian synagogues are, aside from one bathhouse, primarily from elite domestic contexts. ${ }^{11}$ The only exception is the sixth-century mosaic of Helios and Selene surrounded by a zodiac in the Monastery of Lady Mary at Beth She' an. ${ }^{12}$

\footnotetext{
${ }^{11}$ Dining hall (triclinium) of the House of the Calendar (central circle largely destroyed, possibly Helios), Antioch, Syria ( $2^{\text {nd }}$ c. CE); reception hall of a villa rustica in Münster-Sarmsheim, Germany (mid- $3^{\text {rd }}$ c. CE); dining hall of a house (in the central circle is depicted the figures of Selene and Helios; in the corners, the four winds), Sparta, Greece ( $4^{\text {th }} \mathrm{c}$. CE); dining hall of a house, Thessaloniki, Greece $\left(5^{\text {th }}\right.$ c. CE); Tallaras Baths (Helios without a chariot, raising a right hand in a gesture of blessing), Island of Astypalaea, Greece $\left(5^{\text {th }} \mathrm{c}\right.$. CE). For a discussion of this comparative material (with further literature), see Levine 2012, 323-326; Hachlili 2013, 373-382.

${ }^{12}$ Fitzgerald 1939, 6-7, pls. vi-viii.
} 
Another problem surrounding the Helios-and-zodiac motif is the absence of clearly related written sources on the matter. While Josephus explicitly noted the disallowance of zodiac signs in the Jerusalem temple during the Late Second Temple period, ${ }^{13}$ there are still some references to zodiac signs to be found in literature of that time, such as in the Dead Sea scrolls. ${ }^{14}$ They become more abundant, however, in later Jewish literature, such as in some midrashim and piyyutim (Jewish liturgical poetry). ${ }^{15}$ Another example of the use of the zodiac among Jews can be found in the writings of the fourth-century Church Father Epiphanius of Salamis:

Moreover, here again are their Hebrew names for what the misguided futilely regard as planets, though [the Greeks, who] wrongfully misled the world into impiety, call them the signs of the zodiac: Tela', Sor, T’omin, Zar'tan, Ari, Bethulah, Moznaim, 'Akrabh, Qesheth, G'di, Dalli, Daggim. Following the Greeks to no purpose, they, I mean the Pharisees, translated the same terms into Hebrew as follows. Aries is what they call Tela'; Taurus is Sor; Gemini, T'omim; Cancer, Zar'tan; Leo, Ari; Virgo, Bethulah; Libra, Moznaim; Scorpio, 'Akrabh; Sagittarius, Qesheth; Capricorn, G'di; Aquarius, Dalli; Pisces, Daggim. ${ }^{16}$

None of these written sources, however, provides a clear description of any relationship with the artistic evidence found in the synagogues surveyed above. Relevant textual discussions on the Helios figure are even fewer in number. Most prominent among these is the Jewish handbook on practical magic Sefer Ha-Razim (Book of Mysteries; but see also Numbers Rabbah 12.4), which is generally dated to the third or fourth century CE. ${ }^{17}$ The book includes prayers to Helios, who is described there as an archangel:

Holy Helios, who rises in the east, good mariner, trustworthy leader of the sun's rays, reliable (witness), who of old did establish the mighty wheel (of the heavens), holy orderer, ruler of the axis (of the heaven), Lord, Brilliant Leader, King, Soldier. ${ }^{18}$

\footnotetext{
${ }^{13}$ Josephus, BJ 5.214: "On this tapestry [in the Temple] was portrayed a panorama of the heavens, the signs of the Zodiac excepted."

${ }^{14}$ E.g., 4Q138 (Brontologian); 4Q186 (4QHoroscope); cf. Josephus, BJ 5.217. See also 2 Enoch 30: “And I appointed the sun over the illumination of the day, but the moon and stars over the illumination of the night. And the sun goes in accordance with each animal, and the twelve animals are the succession of the months" (Charlesworth 1986, 1:150).

${ }^{15}$ E.g., Tanhuma, Vayehi, 16. For a list of various piyyutim, see Fine 2005, 202-204. It should be noted that, in medieval Ashkenazi manuscripts, images of the zodiac are quite common and, for instance, often accompany piyyutim for rain and dew by Rabbi Eleazar ha-Qalir. This does not, however, necessarily suggest a link between piyyutim and Helios-andzodiac motifs during earlier periods.

${ }^{16}$ Epiphanius, Panarion 16.2.4-5 (trans. Williams 2009, 43-44).

${ }^{17}$ On the dating of this book, see Morgan 1983, 8-11. See further Wandrey 2004, 82-87; Bohak 2009, 251-253.

${ }^{18}$ Morgan 1983, 71.
} 


\section{Different Interpretations of the Helios-and-Zodiac Motif}

Notwithstanding the variation among Helios-and-zodiac motifs, the different contexts in which they appear and the long period over which they were in use, almost all scholars so far have provided monolithic interpretations for all Helios-and-zodiac motifs. One of the earliest such examples comes from E. R. Goodenough, who identified the Helios-and-zodiac motif as representing the God of Israel ruling over the cosmos. ${ }^{19}$ Based on the idea that most Jews were proficient in the iconography of the broader Roman world, Goodenough thought that Jewish communities had effectively appropriated the Helios figure and the astrological signs, adapting it to their own religious context. Hence, he saw these Helios-and-zodiac motifs as evidence of a mystical nonrabbinic Judaism, of which little was preserved in textual sources. The suggestion was highly provocative at the time, because the idea of a monolithic normative rabbinic Judaism as reconstructed from textual sources still constituted the scholarly consensus. Some scholars, therefore, were highly critical of Goodenough's suggestion. They surmised that, by the third and fourth centuries CE, the kind of non-Jewish imagery of a Helios figure had lost its deeper religious significance and, hence, could have been adopted by Jews for merely decorative reasons. ${ }^{20}$ Moreover, because the artists of synagogue floors, as those of other buildings, used copybooks, neither the patrons of the mosaic nor the visitors to the synagogue needed necessarily to have understood the broader cultural connotations of these motifs.

Building forth upon this notion, N. Avigad argued that the motif expressed the general importance of astrology in contemporary Jewish life. ${ }^{21} \mathrm{M}$. Avi-Yonah and his student R. Hachlili, on the other hand, suggested that the Helios-and-zodiac motif carried a particularly Jewish meaning, as the zodiac reflected the centricity of the calendar in Jewish tradition. ${ }^{22}$ Another student of Avi-Yonah, G. Foerster, understood the Helios-and-zodiac motif instead as a symbol of divine cosmic order. ${ }^{23} \mathrm{~A}$ variant of the latter interpretation was given recently of the Helios-and-zodiac motif in the Sepphoris synagogue - according to its excavator, Z. Weiss, the motif signified God's power in history. ${ }^{24} \mathrm{E}$. L. Sukenik noted already early on, in the 1930s, that some of the piyyutim of local Jewish communities clearly express the theme of the zodiac. Based on this connection, he and some recent scholars have argued that the Helios-and-zodiac motif was indeed related to the Jewish calendar and to some kind

\footnotetext{
${ }^{19}$ Goodenough 1953-68, 8:215-218. See also, e.g., Goodman 2007.

${ }^{20}$ E.g., Urbach 1959, 236-237; Ovadiah 2002, 481-509.

21 Avigad 1962; 1976, 282.

22 Avi-Yonah 1964, 56-57; Hachlili 2002, 234-235.

${ }^{23}$ Foerster 1985, 388; 1987, 225.

${ }^{24}$ Weiss 2005, 231-235, 242; 2009.
} 
of divine order. ${ }^{25}$ According to them, it served as a visual accompaniment to the recitation of piyyutim in synagogue liturgy for some local Jewish communities.

Other scholars, such as M. Smith and L. Roussin, have used the Sefer ha-Razim, a handbook on practical magic, to interpret the Helios-and-zodiac motif. ${ }^{26}$ They identify the Helios figure depicted in the mosaics' centres as the archangel, a heavenly intercessor to God on behalf of the congregation. According to this interpretation, the lower panels of the larger composition are to be understood as representing the earthly realm, while the upper panel, with the Torah shrine, stands for the highest sphere. J. Magness recently made an even more specific interpretation based on hekhalot and merkavah literature, suggesting that the Helios figure also represents archangel Metatron and that the depicted chariot should be viewed as his chariot-throne (merkavah). ${ }^{27}$ According to this set of mystical literature, Enoch transformed from a human priest on earth into an angelic priest called Metatron, serving in the heavenly shrines. Furthermore, as Enoch supposedly lived for 365 years, he eventually became associated with the calculation and transmission of the solar calendar. This interpretation perhaps carries further implications on the astrological signs of the zodiac surrounding the Helios figure.

\section{Discussion}

None of the above interpretations is entirely satisfactory. First, the claim that the non-Jewish imagery bore a solely decorative purpose is invalidated by the sheer uniformity and resilience of this artistic motif in synagogues throughout Byzantine Palestine. Indeed, the fact that Jews did not simply add other non-Jewish imagery as decoration in their synagogues is striking. Moreover, the replacement of the Helios figure by a sun in the case of Sepphoris apparently indicates some anxiety regarding this motif among at least some Jewish communities.

Furthermore, the idea that the various Helios-and-zodiac motifs depicted the Jewish calendar remains problematic, as the panels in the zodiac cycle bear no reference at all to the Jewish festival calendar. Indeed, the zodiacal solar calendar with its central Helios figure stands at complete odds to the Jewish lunar calendar. That there were choices to be made in realizing the mosaic motif is evidenced by the

${ }^{25}$ Sukenik 1934, 64-67. See also, e.g., Fine 2005, 186-189, 204-205.

${ }^{26}$ Smith 1982, 209*-210*; Roussin 1997.

${ }^{27}$ Magness 2005. 
fact that some Helios-and-zodiac motifs in non-Jewish contexts (e.g., Sparta and Beth She' an) actually depict - alongside Helios - Selene, goddess of the moon. In light of this piece of evidence, it would seem strange for Jewish patrons in Late Antique Palestine, had they wanted to emphasize a connection with the Jewish lunar calendar, to have chosen a Helios figure above that of Selene. Finally, as mentioned earlier, in half of the preserved zodiac pavements in synagogues, the seasons and months do not actually correspond to one another. This makes any calendrical interpretation, at least in those cases, unlikely.

On the other hand, the connection between the synagogues' Helios-and-zodiac motifs and the archangel in the roughly contemporary magical handbook Sefer ha-Razim, as well as the figure of Metatron in hekhalot literature, sounds more reasonable. One issue with this interpretation, however, is that the larger tripartite mosaic composition reflecting an earthly, celestial, and higher realm is only attested so far at Hammath Tiberias and Beth Alpha. Who among the viewers, moreover, would have understood such deeper references in the Helios figure depicted in synagogues? Aside from his depiction on these mosaic floors, it should be noted, the figure of Helios was also familiar to the general public from depictions on regular coins and oil lamps from that time. ${ }^{28}$ While the precise meaning of these depictions is not always clear to us, a completely Jewish understanding of these common objects seems unlikely.

This point brings the discussion to perhaps the most problematic issue burdening most interpretations surveyed above: the assumption of universal and undifferentiated reception by all Jews, whether patron or viewer, man or woman, child or adult, city or village dweller. Most recently, L. I. Levine argued against such a general approach to the Helios-and-zodiac motif. ${ }^{29}$ Instead, Levine explained the popularity of this motif in synagogues can be traced back to the earliest-known and most impressive appearance of the motif, which was in Hammath Tiberias - at the time, the seat of the Patriarchate and, arguably, the leading Jewish city. ${ }^{30}$ The main patron of the synagogue, mentioned in the mosaic's dedicatory inscriptions, is twice identified as having been closely associated with the "illustrious Patriarch." Given the status and importance of the patriarchate and this city, Levine argues that other Jewish communities might have found the Helios-and-zodiac motif attractive and intriguing

\footnotetext{
${ }^{28}$ For the representation of this figure on a variety of objects in the Roman world, see the extensive catalogue in Hijmans 2009, 103-466.

${ }^{29}$ Levine 2012, 328.

${ }^{30}$ Levine 2012, 329-335.
} 
and therefore eventually adopted it for their own synagogues. According to Levine, this interpretation would also explain the appearance of references to zodiac signs and Helios in some of the textual sources of the time. ${ }^{31}$

Levine's explanation rightfully emphasizes the social, cultural, and communal circumstances rather than ideological and religious ideas. Nevertheless, there are several problems with his argument. The main issue is that we can never be certain that the Helios-and-zodiac motif at Hammath Tiberias was, in fact, the earliest. Rather, as the archaeological method of dating these mosaic floors provides only a date range, it remains possible that Susiya's Helios-and-zodiac motif may have been conceived and realized earlier than at Hammath Tiberias. Furthermore, how and why the Helios-and-zodiac motif eventually ended up in the six other synagogues in particular remains unexplained. The same question lingers over the notable variations between each of the mosaic floors. Furthermore, Levine has no basis for claiming direction of influence when noting the common references to zodiac signs and Helios in some textual sources. In fact, there is no way to know whether the mosaic floors caused the appearance of textual references, or if it happened vice versa. Finally, Levine's explanation for the dissemination of the Helios-and-zodiac motif after its first appearance in Hammath Tiberias is not quite as novel as it first seems; his explanation for why the motif began to be used in the first place can be considered a variation on the earlier idea that the imagery had lost its non-Jewish religious connotations (see above).

Levine is correct, however, in stressing the fact that a single interpretation for the Helios-and-zodiac motif in the different synagogues is too simplistic. While the similarities certainly suggest some kind of cultural and/or religious connection between the different synagogues, variability within the motifs indicates that the local context manifested in different levels of interpretation. Furthermore, most interpretations of the Helios-and-zodiac motif are given from the viewpoint of Jewish patrons of the mosaic who decide on individual themes. Whether ordinary congregation members also understood the motifs depicted in these mosaics in a similar manner remains a separate question. Furthermore, would regular viewers have had different ideas about this motif than occasional visitors of these synagogues?

Our ability to grapple with the understanding of contemporary viewers is inextricably linked to how these viewers engaged with these Helios-and-zodiac motifs. Unfortunately, this must remain for now

\footnotetext{
${ }^{31}$ E.g., Epiphanius, Panarion 16.2.4-5; Sefer ha-Razim.
} 
a highly speculative endeavour, not only because we do not know how each congregant or visitor was shaped by the social, cultural and religious views of their community but because we also know too little about how the Helios-and-zodiac motif functioned in its architectural context. While the centricity of the Helios-and-zodiac motifs in these synagogues indicates their importance to the people who decided on the art and architecture of the building, it is very much possible that, during regular moments of worship, little of the larger motif was visible to the congregants who stood or sat upon it. Moreover, floor tapestries, which are not preserved in the archaeological record for our region, could have occasionally covered over parts of the mosaic. Lightning inside the large hall of the synagogues in which the mosaic was laid out is another aspect that needs to be given more attention to start grasping the viewers' understandings of these motifs. Which parts of the mosaic were visible during the day? Were parts of the mosaic accentuated by artificial light from oil lamps or chandeliers? Finally, the fact that some Helios-and-zodiac motifs were eventually partially replaced by a different type of mosaic (Susiya) or were the victim of iconoclasm ( $\mathrm{Na}$ 'aran) suggests that, at some point in the life of these mosaics, their meaning within some synagogues seems to have changed drastically. This change not only provides information about the community that undertook this change but also gives insight into the meaning previous communities may have given to these mosaics. For example, the destruction of figures in the Na'aran synagogue mosaic suggests that previous communities would have understood and embraced the particular socio-religious meaning of these figures.

This brings me to my last point of the discussion. Not only are most interpretations given by scholars based on the assumption of their all-inclusive validity among synagogue members, they also appear to be guided by the broader discussion on the nature and development of Judaism in Byzantine Palestine. Namely, different interpretations often hinge on the idea that the different Jewish movements of this time were rather discrete and autonomous, with little to no influence upon the goings-on of one another. Hence, as mentioned at the beginning of this chapter, the Helios-and-zodiac motif is interpreted either as evidence for the strength of a mystical and magical Jewish movement during this time or as befitting the complexity of "mainstream" rabbinic Judaism. This division between rabbinic (non-magical, rationalistic) and mystical Judaism also reflects the modern (and ancient) dichotomy between religion and magic, a stereotype according to which "we" practice religion while "others" practice magic. Increasingly, however, scholars are becoming sceptical of the 
claim that these different Jewish movements lived in "splendid isolation" from one another. ${ }^{32}$ What emerges instead is a complex portrait of permeable Jewish movements that developed and transformed through their constant interaction with one another. In light of this broader view, the Helios-andzodiac motif can no longer be understood as symbolizing a "mystical," "magical" or "rabbinic" form of Judaism. Instead, what can be said is that this motif indicates the diversity of Jewish communities of this time.

\section{Bibliography}

Avigad, N., "The Mosaic Pavement of the Beth-Alpha Synagogue and its Place in the History of Jewish Art," in The Beth Shean Valley: The 17th Archaeological Convention (Jerusalem: Israel Exploration Society, 1962), 63-70 (Hebrew).

Avigad, N., Beth She 'arim, Vol. 3: Report on the Excavations during 1953-1958, Catacombs 12-23 (New Brunswick, NJ: Rutgers University Press, 1976).

Avi-Yonah, M., "A Sixth-Century Synagogue at Isfiya," Quarterly of the Department of Antiquities of Palestine 3 (1934), 118-131.

Avi-Yonah, M., "The Caesarea Inscription of the Twenty-Four Priestly Courses," in E. J. Vardaman \& J. L. Garrett (eds), The Teacher's Yoke: Studies in Memory of Henry Trantham (Waco, TX: Baylor University Press, 1964), 45-57.

Barag, D., "Japhia," in E. Stern (ed.), The New Encyclopedia of Arcahaeological Excavations in the Holy Land, Vol. 2. (Jerusalem: Israel Exploration Society, 1993), 659-660.

Bohak, G., Ancient Jewish Magic: A History (Cambridge: Cambridge University Press, 2008).

Boustan, R., "Rabbinization and the Making of Early Jewish Mysticism," Jewish Quarterly Review 101 (2011), 482-501.

Charlesworth, J. H., The Old Testament Pseudepigrapha, Vol. 1: Apocalyptic Literature and Testaments (The Anchor Yale Bible Reference Library; New Haven: Yale University Press, 1983).

Dothan, M., Hammath Tiberias, Vol. 1: Early Synagogues and the Hellenistic and Roman Remains (Jerusalem: Israel Exploration Society, 1983).

\footnotetext{
${ }^{32}$ See Boustan 2011, with earlier literature.
} 
Dunbabin, K. M. D., Mosaics of the Greek and Roman World (Cambridge: Cambridge University Press, 1999).

Fitzgerald, G. M., A Sixth-Century Monastery at Beth-Shan (Scythopolis) (Publications of the Palestine Section of the University Museum 4; Philadelphia: University of Pennsylvania Museum of Archaeology and Anthropology, 1939).

Foerster, G., "Representations of the Zodiac in Ancient Synagogues and Their Iconographic Sources," Eretz Israel 18 (1985), 380-391 (Hebrew).

Foerster, G., "The Zodiac in Ancient Synagogues and Its Place in Jewish Thought and Literature," Eretz Israel 19 (1987), 225-234 (Hebrew).

Goodenough, E. R. Jewish Symbols in the Greco-Roman Period, 13 Vols (Princeton: Princeton University Press, 1953-68).

Goodman, M. D., "The Jewish Image of God in Late Antiquity," in M. D. Goodman (ed.), Judaism in the Roman World: Collected Essays (Ancient Judaism and Early Christianity 66; Leiden: Brill, 2007), 205-217.

Gutman, S., Z. Yeivin, and E. Netzer, "Excavation in the Synagogue at Horvat Susiya," in L. I. Levine (ed.), Ancient Synagogues Revealed (Jerusalem: Israel Exploration Society, 1981), 123-128.

Hachlili, R., "The Zodiac in Ancient Synagogal Art: A Review," Jewish Studies Quarterly 9 (2002), 219-258.

Hachlili, R., Ancient Synagogues-Archaeology and Art: New Discoveries and Current Research (Handbuch der Orientalistiek 1.105; Leiden: Brill, 2013).

Hijmans, S. E., "Sol: The Sun in the Art and Religions of Rome" (Unpublished PhD diss., University of Groningen, 2009).

Leibner, U. and S. Miller, "A Figural Mosaic in the Synagogue at Khirbet Wadi Hamam," Journal of Roman Archaeology 23 (2010), 238-264.

Levine, L. I., Visual Judaism in Late Antiquity. Historical Contexts of Jewish Art (New Haven, CT: Yale University Press, 2012).

Magness, J., "Heaven on Earth: Helios and the Zodiac Cycle in Ancient Palestinian Synagogues," Dumbarton Oaks Papers 59 (2005), 1-52.

Magness, J., S. Kisilevitz, K. Britt, M. J. Grey, and C. S. Spigel, "Huqoq (Lower Galilee) and Its Synagogue Mosaics: Preliminary Report on the Excavations of 2011-13," Journal of Roman Archaeology 27 (2014), 327-355. 
Magness, J., S. Kisilevitz, M. Grey, D. Mizzi, D. Schindler, M. Wells, K. Britt, R. Boustan, S. O’Connell, E. Hubbard, J. George, J. Ramsay, E. Boaretto, and M. Chazan. "The Huqoq Excavation Project: 2014-2017 Interim Report.” Bulletin of the American Schools of Oriental Research 380 (2018): 61-131.

Morgan, M. A., Sepher Ha-Razim: The Book of the Mysteries (SBL Texts and Translations 25; SBL Pseudepigrapha Series 11; Chico, TX: Scholars Press, 1983).

Ovadiah, A., Art and Archaeology in Israel and Neighbouring Countries (London: Pindar Press, 2002).

Roussin, L. A., “The Zodiac in Synagogue Decoration,” in D. R. Edwards and C. T. McCollough (eds), Archaeology and the Galilee: Texts and Contexts in the Graeco-Roman and Byzantine Periods (Atlanta: Scholars Press, 1997), 83-96.

Schwartz, S., "Historiography on the Jews in the "Talmudic Period" (70-640 CE)," in M. D. Goodman (ed.), Oxford Handbook of Jewish Studies (Oxford: Oxford University Press, 2002), 79-114.

Smith, M., "Helios in Palestine,” Eretz-Israel 16 (1982), 199*_214*.

Sukenik, E. L., The Ancient Synagogue of Beth-Alpha (Jerusalem: Magnes Press, 1932).

Sukenik, E. L., Ancient Synagogues in Palestine and Greece (London: British Academy, 1934).

Urbach, E. E., "The Rabbinical Laws on Idolatry in the Second and Third Centuries in the Light of Archaeological and Historical Facts," Israel Exploration Journal 9 (1959), 149-165, 229-245.

Veltri, G., "Magic and Healing," in C. Hezser (ed.), The Oxford Handbook of Jewish Daily Life in Roman Palestine (Oxford: Oxford University Press, 2010), 587-602.

Vincent, L.-H., “Le sanctuaire juif de’Ain-Doug,” Revue biblique 16 (1919), 532-563.

Vincent, L.-H., “Le sanctuaire juif de’Ain-Doug,” Revue biblique 30 (1920), 442-443.

Vincent, L.-H., "Une sanctuaire dans la region de Jericho, la synagogue de Na'aren,” Revue biblique 68 (1961), 163-177.

Wandrey, I., 'Das Buch des Gewandes' und 'Das Buch des Aufrechten': Dokumente eines magischen spätantiken Rituals, ediert, kommentiert und übersetzt (Texts and Studies in Ancient Judaism 96; Tübingen: Mohr Siebeck, 2004).

Weiss, Z., The Sepphoris Synagogue: Deciphering an Ancient Message Through Its Archaeological and Socio-Historical Contexts (Jerusalem: Israel Exploration Society, 2005). 
Weiss, Z., "Between Rome and Byzantium: Pagan Motifs in Synagogue Art and Their Place in the Judaeo-Christian Controversy," in L. I. Levine and D. R. Schwartz (eds), Jewish Identities in Antiquity: Studies in Memory of Menahem Stern (Tübingen: Mohr Siebeck, 2009), 367-390. 